\title{
The Changes of Nutrient Composition and In Vitro Evaluation on Gamma Irradiated Sweet Sorghum Bagasse
}

\section{Perubahan Komposisi Nutrien dan Evaluasi In Vitro Pada Bagas Sorgum Manis Hasil Iradiasi Gamma}

\section{Teguh Wahyono and Firsoni}

Center for The Isotope and Radiation Application

National Nuclear Energy Agency

Lebak Bulus Raya St. 49 South Jakarta, 12440

Email : teguhwahyono@batan.go.id

Diterima 28-03-2016; Diterima dengan revisi 26-04-2016; Disetujui 02-06-2016

\begin{abstract}
The Changes of Nutrient Composition and In Vitro Evaluation on Gamma Irradiated Sweet Sorghum Bagasse. In vitro rumen fermentation study was done to evaluate the effects of gamma irradiation on nutrient compound changes and rumen fermentation product of sweet sorghum bagasse (SSB). The level doses 0, 50, 100 and $150 \mathrm{kGy}$ from cobalt-60 gamma rays irradiator was used to treate sweet sorghum bagasse (SSB). Variables measured were nutrient values, gas production, methane $\left(\mathrm{CH}_{4}\right)$ production, total volatile fatty acid (TVFA), ammonia $\left(\mathrm{NH}_{3}\right)$, in vitro dry matter digestibility (IVDMD) and in vitro organic matter digestibility (IVOMD) after $72 \mathrm{~h}$ in-vitro incubation times. Complete randomized design (CRD) (four treatments and four replications) was used to analyze data. The results showed that gamma irradiation doses of 50,100 and $150 \mathrm{kGy}$ were able to reduce neutral detergent fibre (NDF) $(2.15 ; 3.29$ and $5.44 \%$ respectively) and acid detergent fibre (ADF) $(3.29 ; 4.58$ and $4.58 \%$ respectively) and significantly different $(\mathrm{P}<0.05)$. Gamma irradiation was capable to increas total volatile fatty acid (TVFA), IVDMD and IVOMD $(\mathrm{P}<0.05)$. Irradiation doses of 100 and $150 \mathrm{kGy}$ also increased protozoa population and $\mathrm{CH}_{4}$ production significantly $(\mathrm{P}<0.05)$. Gamma irradiation improved in vitro rumen performance represented in rumen fermentation products.
\end{abstract}

Keywords : Gamma irradiation, In vitro fermentation, Nutrient composition, Sweet sorghum bagasse

\begin{abstract}
ABSTRAK
Perubahan Komposisi Nutrien dan Evaluasi In Vitro Pada Bagas Sorgum Manis Hasil Iradiasi Gamma. Studi fermentasi rumen secara in vitro dilakukan untuk mengevaluasi pengaruh iradiasi gamma terhadap perubahan nutrien dan produk fermentasi rumen dari substrat bagas sorgum manis (SSB). Dosis iradiasi yang digunakan sebesar 0, 50, 100 dan $150 \mathrm{kGy}$ bersumber dari cobalt-60. Variabel yang diamati adalah komposisi nutrien, produksi gas total, produksi gas metana $\left(\mathrm{CH}_{4}\right)$, total volatile fatty acid (TVFA), amonia $\left(\mathrm{NH}_{3}\right)$, degradasi bahan kering in vitro (IVDMD) dan degradasi bahan organik in vitro (IVOMD) setelah inkubasi selama 72 jam. Penelitian ini menggunakan rancangan acak lengkap (RAL) empat perlakuan dan empat ulangan. Hasil penelitian menunjukkan bahwa iradiasi sinar gamma dosis 50, 100 dan $150 \mathrm{kGy}$ dapat menurunkan fraksi neutral detergent fiber (NDF) masing-masing sebesar 2,15; 3,29 dan 5,44\% dibandingkan kontrol $(\mathrm{P}<0,05)$. Ketiga dosis tersebut juga dapat menurunkan fraksi acid detergent fiber (ADF) sebesar 3,29; 4,58 dan 4,58\% $(\mathrm{P}<0,05)$. Iradiasi gamma meningkatkan produk fermentasi rumen berupa produksi TVFA, IVDMD dan IVOMD $(\mathrm{P}<0,05)$. Dosis 100 dan $150 \mathrm{kGy}$ juga yang meningkatkan populasi protozoa dan produksi $\mathrm{CH}_{4}(\mathrm{P}<0,05)$. Iradiasi gamma pada SSB dapat meningkatkan kinerja rumen secara in vitro yang direpresentasikan dari produk fermentasi rumen.
\end{abstract}

Kata kunci : Bagas sorgum, Fermentasi in vitro, Iradiasi Gamma, Komposisi nutrien 


\section{INTRODUCTION}

Bio-ethanol of sorghum was produced from the sweet sorghum stalks after grain harvest. Sweet sorghum bagasse (SSB) is byproduct from sweet sorghum stem after extraction. This by-product is suitable to be used for ruminant's diets and also gives economics impact from bio-ethanol production [1]. SSB has high fiber content, low palatability and poor nutrient due to low degradability fiber or complex carbohydrates [2] femained after bio-ethanol process.

Improvement of degradability of byproducts feed chemical component have been done recently. Physical and chemical treatments were used to improve nutritional value of sugarcane bagasse [3]. Wright et al. [4] reported that heat and lignosulfonatetreated of canola meal able to decrease the protein ruminal degradation and improve protein value for lactating dairy cows. Dogaris et al. [5] investigated using Neurospora crassa and Fusarium oxysporum fungi to increase the depolymerize of lignocellulosic components on SSB. Yan et al. [6] investigated the effect of $\mathrm{NaOH}$ and $\mathrm{Ca}(\mathrm{OH})_{2}$ on cellulose degradation in SSB. Some of methods above were dangerous for livestock because of chemical-environmental pollution.

The processing methods which material exposed to gamma rays has been recognized as a reliable and safe method to improve the nutritive value of corn stalk [7], soybean meal [8], alfalfa hay [9], canola seed [10] and other agricultural by-product [11]. Feed irradiation with gamma rays emitted from radioisotope Cobalt-60 used for improve nutrient quality and rumen degradation. There were only little literature and information about the effects of gamma irradiation on nutritient values and in vitro ruminal fermentation characteristics of SSB. Therefore SSB need to be conducted by evaluating the effects of some levels of gamma irradiation doses on nutrient composition and in vitro rumen fermentation.

\section{MATERIAL AND METHOD}

\section{Samples Preparation and Treatments}

Samurai 1 sweet sorghum variety harvested at 100 days. SSB is by-product from sweet sorghum stem after extraction. Samples were dried at $60^{\circ} \mathrm{C}$ and ground to pass a fine particle size. Cobalt-60 Gamma irradiation in Center for the Application of Isotopes and Radiation, Indonesia National Nuclear Energy Agency was used to treat the three polyethylene packages of samples at 3 level doses (50, 100 and $150 \mathrm{kGy})$. Samples were analyze for dry matter (DM), crude protein $(\mathrm{CP})$, ether extract (EE), crude fiber $(\mathrm{CF})$ and ash content by procedures of AOAC [12]. NDF and ADF were analyzed using Goering and Van Soest [13] procedures.

\section{In Vitro Study and Fermentation Technique}

Rumen fluid was collected from fistulated buffalo bull with $330 \mathrm{~kg}$ live weight. The diets of Buffalo were containing field grass (Digitaria sp., Setaria barbata, Axonopus compressus dominate) (ad libitum) and concentrate $(0,5 \%$ body weight) based on DM. Diet formulation contain $13 \%$ CP of DM. Buffalo bull was fed twice daily at 08:30 and 15:30 h. Rumen fluid was collected from middle part of the rumen. The $650 \mathrm{ml}$ rumen liquor was obtained from fistulated buffalo before the morning feeding. Rumen fluid was filtered through four layers of cheesecloth and warmed in incubator at $39^{\circ} \mathrm{C}$. Preparation of artificial saliva, fermentation solution and sample incubation were done according to [14]. The $100 \mathrm{ml}$ glass syringe (Fortuna model, Germany) with the mixture sample treatments were pre-warmed in a waterbath at $39^{\circ} \mathrm{C}$ for $1 \mathrm{~h}$ before filling with $30 \mathrm{ml}$ buffer-rumen. Gas production measurements were performed at $0,2,4,6$, $8,10,12,24,48$ and 72 h. Rumen fermentation parameters were collected at $72 \mathrm{~h}$ incubation. 


\section{Determination of Fermentation Parameters}

Total gas production, $\mathrm{CH}_{4}$ concentration and sample inoculum were collected after $72 \mathrm{~h}$ incubation. Measurement of $\mathrm{CH}_{4}$ concentration was determined using MRU gas analyzer. Measurement of TVFA was done using AOAC (2010). $\mathrm{NH}_{3}$ measurement was using conway microdifusion methods [15]. The $\mathrm{DM}$ and $\mathrm{OM}$ degradation measurement were determined according to the calculation Blummel et al. [16]. Protozoa population was measured by Ogimoto and Imai [17].

\section{Statistical Analyses}

Experimental design used completely randomized design (CRD) in four treatments and four replications. SPSS 16 was used to analyzed data, with the following statistical model as follows:

$$
\mathrm{Y}_{\mathrm{ij}}=\mu+\alpha_{\mathrm{i}}+\varepsilon_{\mathrm{ij}}
$$

insoluble fraction, $\mathrm{c}$ is the gas production rate constant from insoluble fraction, $t$ is incubation time, $(a+b)$ is the potential extent of gas production and $\mathrm{P}$ is gas produced at " $t$ " time. Differences between treatment were analyzed using Duncan's Multiple Range Test [19].

\section{RESULTS AND DISCUSSIONS}

\section{Nutrient Composition}

Nutrient composition of untreated and gamma irradiated SSB are presented in Table 1. There was no effect of Gamma Irradiation on dry matter, crude protein, ether extract and ash composition on SSB. The dose levels of 50,100 and $150 \mathrm{kGy}$ was able to decrease NDF content by $2.15 ; 3.29$ and $5.44 \%$ $(\mathrm{P}<0.05)$ respectively. The same dose treatments also decreased ADF content by 3.29; 4.58 and $4.58 \%(\mathrm{P}<0.05)$ respectively.

Gamma irradiation had no significant effect on dry matter, crude protein, ether

Table 1. Nutrient composition untreated and gamma irradiated of SSB (g/kg Dry Matter)

\begin{tabular}{lcccccc}
\hline \multicolumn{1}{c}{ Treatment } & Dry matter & Crude protein & Ether extract & Ash & NDF & ADF \\
\hline Untreated & 941 & 54.0 & 18.5 & 84.5 & $791^{\mathrm{a}}$ & $486^{\mathrm{a}}$ \\
$50 \mathrm{kGy}$ & 931 & 59.3 & 17.3 & 83.9 & $774^{\mathrm{b}}$ & $470^{\mathrm{b}}$ \\
$100 \mathrm{kGy}$ & 932 & 59.5 & 16.7 & 83.0 & $765^{\mathrm{b}}$ & $454^{\mathrm{c}}$ \\
$150 \mathrm{kGy}$ & 934 & 62.4 & 18.5 & 83.2 & $748^{\mathrm{c}}$ & $454^{\mathrm{c}}$ \\
\hline SEM & 1.9 & 0.2 & 0.8 & 0.8 & 5 & 4.3 \\
\hline
\end{tabular}

NDF: neutral detergent fiber; ADF: acid detergent fiber; SEM: standard error of mean; Each value is a mean of four samples; ${ }^{\text {a-c }}$ : means within a columns followed by a different letter differ significantly $(\mathrm{P}$ $<0.05)$.

Where, $\mathrm{Y}$ is the dependent variable, $\mu$ is the overall mean, $\alpha_{i}$ is the gamma irradiation effect and $\varepsilon_{\mathrm{ij}}$ is the residual error. Cumulative total gas production data are fitted to gas kinetics with software NEWAY ${ }^{\circledR}$ based with Ørskov and McDonald [18] model as follows:

$$
P=a+b\left(1-e^{-c t}\right)
$$

Where, $a$ is the gas production from soluble fraction, $b$ is the gas production from extract and ash composition $(20,21]$. In other study, chemical composition of soybean was unaffected by gamma irradiation [20]. There was no effect occurred on some studies using lower dose of gamma irradiation $(<45 \mathrm{kGy})$. Anwar et al. [11] and Shawrang et al. [22] reported that irradiation doses levels 10, 20 and $30 \mathrm{kGy}$ were not affecting on the chemical composition of canola seeds. Ebrahimi-Mahmoudabad and Taghinejad-Roudbaneh [23] also concluded that lower irradiation dose $(<45 \mathrm{kGy})$ was 
not sufficient to change chemical composition of whole cottonseed, soybean and canola seeds. The same effects were also happened at higher doses.

Gamma irradiation dose of $150 \mathrm{kGy}$ could affect in the lowest NDF value content, but the ADF fraction was not significant different compared to $100 \mathrm{kGy}$ dose (Table 1). It was proved that $100 \mathrm{kGy}$ gamma irradiation dose was sufficient to decrease NDF and ADF content. This dose also needed to improve alfalfa hay digestibility [10]. The decrease of NDF and ADF was caused by gamma irradiation where it is able to cut some lignohemicellulose and lignocellulose chains. Increasing the ratio of lignocellulose and crude fiber because of decreasing NDF and ADF. Banchorndhevakul [8] informed that NDF and ADF were decreased after irradiation treatment due to degradation of cellulose and hemicellulose into soluble

\section{Gas Production}

Total gas production and kinetics after $72 \mathrm{~h}$ incubation are presented in Table 2 . Gamma irradiation dose of $150 \mathrm{kGy}$ increased total gas production $11.01 ; 13.85$ and $6.57 \%$ on 2,4 and $6 \mathrm{~h}$ incubations respectively $(\mathrm{P}<0.05)$. On 48 and $72 \mathrm{~h}$ incubation, there were no significant effect between untreated and $150 \mathrm{kGy}$ gamma irradiated SSB. There were no significant effect on total gas production during early incubation between dose level at 50 and 150 kGy gamma irradiation. Gas production from soluble fraction (a) were significantly different after 100 and $150 \mathrm{kGy}$ dose level gamma irradiation $(\mathrm{P}<0.05)$. Nevertheless, gas production from insoluble fraction (b) and potential extent of gas production $(a+b)$ on $100 \mathrm{kGy}$ gamma irradiation treatment were lower than untreated SSB. Gas production rate fraction (c) has no affected by gamma irradiation.

Table 2. Total gas production, $\mathrm{a}+\mathrm{b}$ and c constant of untreated and gamma irradiated SSB after $72 \mathrm{~h}$ incubation

\begin{tabular}{|c|c|c|c|c|c|c|c|c|c|c|c|c|c|}
\hline \multirow{2}{*}{ Treatment } & \multicolumn{9}{|c|}{ Time collection $(\mathrm{h})$} & \multicolumn{4}{|c|}{ Gas kinetics } \\
\hline & 2 & 4 & 6 & 8 & 10 & 12 & 24 & 48 & 72 & $\mathrm{a}$ & $\mathrm{b}$ & $a+b$ & $\mathrm{c}$ \\
\hline Untreated & $4.45^{\mathrm{a}}$ & $7.77^{\mathrm{a}}$ & $10.34^{\mathrm{a}}$ & 12.90 & 15.09 & 16.82 & 28.52 & $42.70^{\mathrm{b}}$ & $51.07^{\mathrm{b}}$ & $1.99^{\mathrm{a}}$ & $59.13^{\mathrm{b}}$ & $61.12^{\mathrm{b}}$ & 0.025 \\
\hline $50 \mathrm{kGy}$ & $4.73^{\mathrm{ab}}$ & $7.78^{\mathrm{a}}$ & $10.37^{\mathrm{a}}$ & 12.82 & 14.95 & 16.48 & 28.30 & $41.65^{\mathrm{ab}}$ & $48.59^{\mathrm{a}}$ & $2.28^{\mathrm{ab}}$ & $57.58^{\mathrm{ab}}$ & $59.85^{\mathrm{ab}}$ & 0.025 \\
\hline $100 \mathrm{kG} y$ & $4.88^{\mathrm{ab}}$ & $8.16^{\mathrm{ab}}$ & $10.75^{\mathrm{ab}}$ & 13.04 & 15.25 & 16.70 & 27.60 & $40.95^{\mathrm{a}}$ & $48.42^{\mathrm{a}}$ & $2.68^{\mathrm{b}}$ & $54.12^{\mathrm{a}}$ & $56.8^{\mathrm{a}}$ & 0.026 \\
\hline $150 \mathrm{kGy}$ & $4.94^{\mathrm{b}}$ & $8.36^{\mathrm{b}}$ & $11.02^{\mathrm{b}}$ & 13.15 & 15.28 & 16.87 & 28.04 & $41.80^{\mathrm{ab}}$ & $49.47^{\mathrm{ab}}$ & $2.75^{\mathrm{b}}$ & $55.85^{\mathrm{ab}}$ & $58.60^{\mathrm{ab}}$ & 0.025 \\
\hline SEM & 0.079 & 0.099 & 0.098 & 0.095 & 0.103 & 0.110 & 0.176 & 0.246 & 0.401 & 0.097 & 0.648 & 0.638 & 0.000 \\
\hline
\end{tabular}

a: gas production from soluble fraction; b: gas production from insoluble fraction; c: gas production rate constant for the insoluble fraction $(b) ; a+b$ : potential extent of gas production: SEM: standard error of mean; Each value is a mean of four samples; ${ }^{a b}$ : means within a columns followed by a different letter differ significantly $(\mathrm{P}<0.05)$.

materials. Decrease of NDF and ADF in irradiated roughages due to depolymerisation and delignification proportional to increase of irradiation dose [24]. This study was similar with the results from Flachowsky et al. [25] and Shawrang et al. [21]. The NDF and ADF content of wood by-products were decreased after irradiation dose over the range $100-2000$ $\mathrm{kGy}$ [25] and after electron beam irradiation with 250 and $500 \mathrm{kGy}$ dose [21].
Total gas production in the dose of 150 kGy irradiation was higher than untreated during 2, 4 and $6 \mathrm{~h}$ incubation time. This was caused by increasing the potential for carbohydrates degradable fraction after irradiation treatment. This was evidenced by a high fraction of gas production from the soluble fraction (a). Total gas production after $72 \mathrm{~h}$ on 50 and $100 \mathrm{kGy}$ gamma irradiation dose were lower than untreated samples $(\mathrm{P}<0.05)$. This study was similar to Deocaris et al. [26] that informed total gas 
production in irradiated chicken feathers with 25 and $50 \mathrm{kGy}$ dose had lower value than untreated samples. High value of "a" fraction was also obtained at $100 \mathrm{kGy}$ irradiation treatment.

\section{$\mathrm{CH}_{4}$ Production}

The $\mathrm{CH}_{4}$ concentration and production are presented in Figure 1 and 2. There were significant effect of gamma irradiation on rumen $\mathrm{CH}_{4}$ concentration and production. Gamma irradiation dose level at 50,100 and $150 \mathrm{kGy}$ increased $\mathrm{CH}_{4}$ concentration (\%) by 56.39 up to 89.66 and $105.07 \% \quad(\mathrm{P}<0.05)$ respectively (Figure 1). Gamma irradiation dose levels of 50, 100 and $150 \mathrm{kGy}$ increased significantly $\mathrm{CH}_{4}$ production $(\mathrm{ml} / 100 \mathrm{mg}$ IVOMD) by 42.68 up to 89.43 and $91.06 \%$ $(\mathrm{P}<0.05)$ respectively, but there was no signficant effect on 100 and $150 \mathrm{kGy}$ dose level (Figure 2).

Gamma irradiation treatment was able to increase $\mathrm{CH}_{4}$ gas production due to breaking down the linkage between polysaccharides and lignin. This was caused by cellulose and hemicellulose more digestible for microbes enzyme activity [27]. Sambusiti et al. [28] reported that lignocellulosic substrates, the methane production of roughages mainly depends on their complex structure which limits their degradability. Irradiation pre-treatments

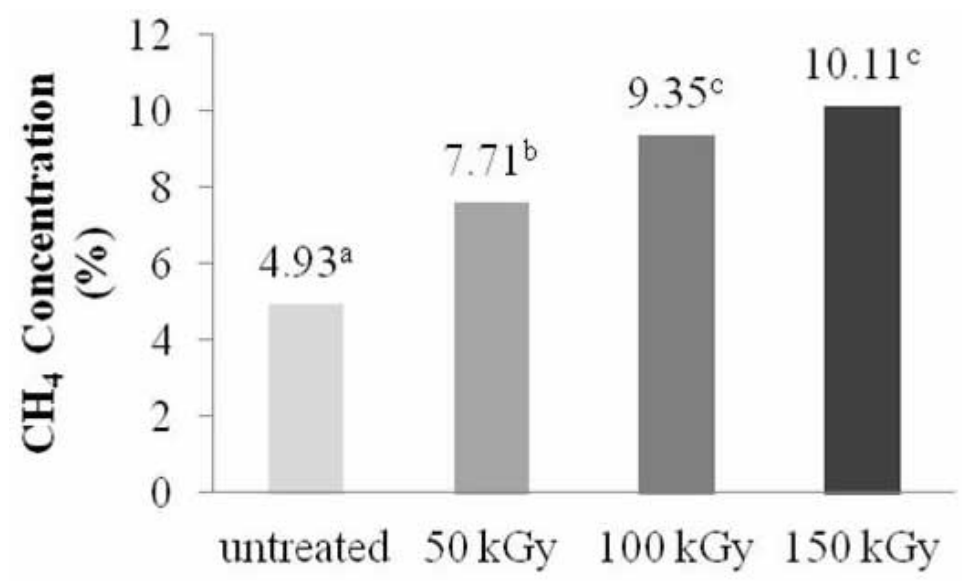

Figure 1. $\mathrm{CH}_{4}$ concentration of untreated and gamma irradiated SSB on $72 \mathrm{~h}$ incubation

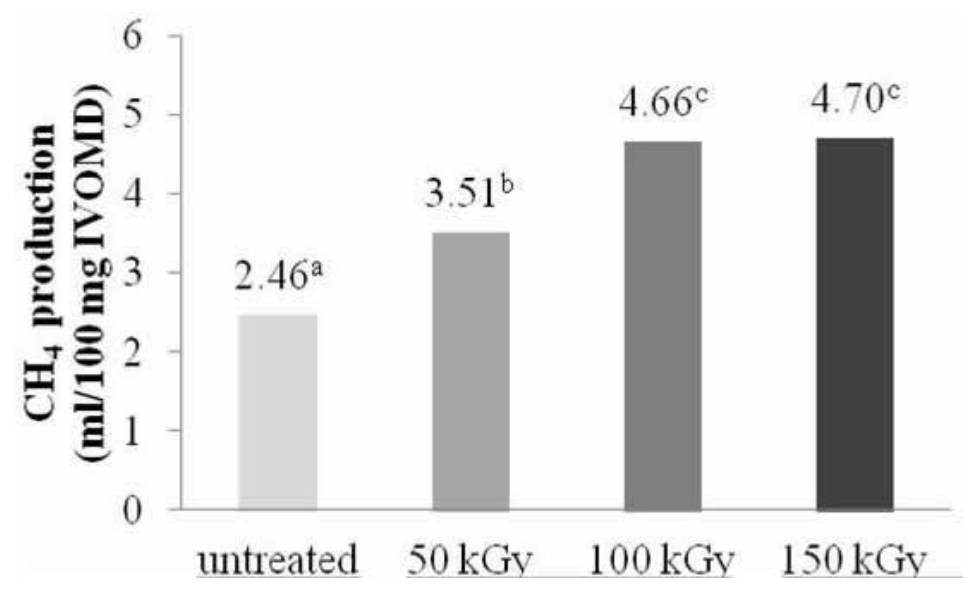

Figure 2. $\mathrm{CH}_{4}$ production of untreated and gamma irradiated SSB on $72 \mathrm{~h}$ incubation 
could accelerate the hydrolysis process, therefore was able to improve the final $\mathrm{CH}_{4}$ gas production.

The increase of $\mathrm{CH}_{4}$ production have relationship with the decrease of NDF and ADF fraction after gamma irradiation pretreatment (Table 1). The decrease value were followed by plysaccharides and lignin linkage breakdown that increase degradability for microbes activity. Increasing levels of crude fiber biodegradable also resulted in increasing of cellulolytic bacteria activity that increase the availability for $\mathrm{CH}_{4}$ inhibitor agent. The $\mathrm{CO}_{2}$ and $\mathrm{H}_{2}$ are mainly produced during fermentation of hemicellulose as structural carbohydrate $[29,30] . \mathrm{CH}_{4}$ was produced by $\mathrm{CO}_{2}$ and $\mathrm{H}_{2}$ reduction that catalyzed by enzyme which secreted by methanogen microbes. Santoso et al. [31] reported that there was a strong relationship between $\mathrm{CH}_{4}$ production (g/day) and NDF digested (g/day) $(\mathrm{r}=0.88)$. Estermann et al. [32] also reported that there was a strong relationship between NDF intake and $\mathrm{CH}_{4}$ production. Another reason for the increasing of fiber hydrolysis after gamma irradiated was a cellulose crystallinity reduction. The crystallinity reduction of cellulose was evident at doses above $100 \mathrm{kGy}$ [33]. Moss and Givens [34] reported that $\mathrm{CH}_{4}$ production had positive correlated with NDF content $(\mathrm{r}=0.79)$. Santoso et al. [31] and Singh et al. [35] also reported that carbohydrate fractions (NDF and $\mathrm{ADF}$ ) were better $\mathrm{CH}_{4}$ predictors than other feed components. Nevertheless, in this study had different result. This was able to increase of NDF degradability after gamma irradiation pretreatment.

\section{Rumen Fermentation Products}

In vitro rumen fermentation products of SSB are presented in Table 3. Gamma irradiation had no effect on $\mathrm{pH}$ and $\mathrm{NH}_{3}$ values. Gamma irradiation dose levels of 50, 100 and $150 \mathrm{kGy}$ increased TVFA product $(\mathrm{P}<0.05)$. These values were 42.02 up to 65.22 and $84.06 \%$. Gamma irradiation dose levels of 100 and $150 \mathrm{kGy}$ also increased protozoa population by 66.25 and $83.75 \%$ respectively $(\mathrm{P}<0.05)$. The IVDMD and IVOMD also increased significantly different $(\mathrm{P}<0.05)$ due to gamma irradiation on dose levels 50, 100 and $150 \mathrm{kG}$. These values were $4.33 ; 7.20$ and $8.15 \%$ (IVDMD) and $4.70 ; 8.29$ and $8.36 \%$ (IVOMD) respectively.

Gamma irradiation had no effect on $\mathrm{NH}_{3}$ concentration due to similar crude protein values between treatments (Table 1). Anwar et al. [11] reported that Gamma irradiation had significant effect on reducing anti-nutritional factors, increasing protein functional properties and in-vitro protein digestibility. The reason of improvement crude protein (CP) digestibility by modificated and denaturated in the three dimensional structure of proteins due to irradiation [23]. Gamma irradiation dose of 50, 100 and $150 \mathrm{kGy}$ was not yet able to improve the digestibility of proteins. It

Table 3. In vitro rumen fermentation product of untreated and gamma irradiated SSB after $72 \mathrm{~h}$ incubation

\begin{tabular}{lcccccc}
\hline Treatment & $\mathrm{pH}$ & $\begin{array}{c}\mathrm{NH}_{3} \\
(\mathrm{mg} / 100 \mathrm{ml})\end{array}$ & $\begin{array}{c}\text { TVFA } \\
(\mathrm{mM})\end{array}$ & $\begin{array}{c}\text { Protozoa } \\
(\mathrm{sel} / \mathrm{ml})\end{array}$ & $\begin{array}{c}\text { IVDMD } \\
(\%)\end{array}$ & $\begin{array}{c}\text { IVOMD } \\
(\%)\end{array}$ \\
\hline Untreated & 7.11 & 17.00 & $46.00^{\mathrm{a}}$ & $0.80 \times 10^{6 \mathrm{a}}$ & $55.83^{\mathrm{a}}$ & $57.44^{\mathrm{a}}$ \\
$50 \mathrm{kGy}$ & 7.18 & 18.00 & $65.33^{\mathrm{b}}$ & $0.80 \times 10^{6 \mathrm{a}}$ & $58.25^{\mathrm{b}}$ & $60.14^{\mathrm{b}}$ \\
$100 \mathrm{kGy}$ & 7.16 & 16.67 & $76.00^{\mathrm{bc}}$ & $1.33 \times 10^{6 \mathrm{~b}}$ & $59.85^{\mathrm{c}}$ & $62.20^{\mathrm{b}}$ \\
$150 \mathrm{kGy}$ & 7.15 & 12.67 & $84.67^{\mathrm{c}}$ & $1.47 \times 10^{6 \mathrm{~b}}$ & $60.38^{\mathrm{c}}$ & $62.24^{\mathrm{b}}$ \\
\hline SEM & 0.014 & 0.857 & 4.586 & 0.111 & 0.569 & 0.661 \\
\hline
\end{tabular}

$\mathrm{NH}_{3}$ : ammonia; TVFA: total volatile fatty acid; IVDMD: in vitro dry matter degradability; IVOMD: in vitro organic matter degradability; SEM: standard error of mean; Each value is a mean of four samples; ${ }^{\text {ab }}$ : means within a columns followed by a different letter differ significantly $(\mathrm{P}<0.05)$. 
represented by no significant concentration of $\mathrm{NH}_{3}$ obtained. Nevertheless, the concentration of $\mathrm{NH}_{3}$ on four treatments met the optimum level. The optimal concentration of buffalo rumen microbial fermentation in a closed system culture is 5 $\mathrm{mg} / 100 \mathrm{ml}$, but also depends on the feed fermentability level $[36,37]$. High concentration results of $\mathrm{NH}_{3}$ was caused by fermentation products covered culture techniques which resulted in the absence of $\mathrm{NH}_{3}$ uptake. It causes high accumulated concentrations of $\mathrm{NH}_{3}$.

Gamma irradiation was effective to increase TFVA production from SSB. This values had strong relationship with decreasing NDF and ADF fractions value (Table 1), that was caused by microbes enzyme activity on cellulose and hemicellulose digestion after gamma irradiation pretreatment. Untreated SSB had the lowest TVFA because there was exist a lignin matrix associated with cellulose and hemicellulose reduced microbial rumen activity on cell wall fraction [10]. Shawrang et al. [9] presented that irradiation treatment could effect to lignocellulosic bonds. The final product of carbohydrate fermentation represented by value of TVFA. The higher irradiation dose, more higher NDF and ADF degradability of barley straw $(\mathrm{P}<0.01)$. The dose of $100 \mathrm{kGy}$ was capable of increasing the degradability of NDF and to be NDF effectively at rumen outflow rate $0.05 \mathrm{~h}^{-1}$ by about 3\% [38]. Siddhuraju et al. [39] also reported that high levels of irradiation could be used to improve degradability of the crude fiber on various plant residues and cereal straws. $\mathrm{CH}_{4}$ production (Figure 1) could be increased as long as increasing of TVFA production. Rapidly NDF degradation increased hydrogen-fermented carbohydrates production that initiate $\mathrm{CH}_{4}$ formation [40].

Gamma irradiated dose levels of 100 and $150 \mathrm{kGy}$ were effective to increase protozoa population (Table 3) and influenced by optimal concentrations of $\mathrm{NH}_{3}$ and availability fraction of degradable NDF and ADF. Optimal concentration of $\mathrm{NH}_{3}$ supported the microbial protein synthesis development. Availability fraction of degradable NDF and ADF would support cellulolytic bacteria population growth, but protozoa like easy substrate digest such as starch, sugar and bacteria as a source of food [41]. Carbohydrates fermented by protozoa to produce $\mathrm{CO}_{2}, \mathrm{H}_{2}$ and VFA, wherever $\mathrm{CO}_{2}$ and $\mathrm{H}_{2}$ are a major precursor of $\mathrm{CH}_{4}$ formation. Increasing of protoza population was accompanied by increasing of $\mathrm{CH}_{4}$ gas production (Figure 1).

Increase of IVDMD and IVOMD after gamma irradiation were influenced by several factors that have been analyzed previously. These factors included the degradable of NDF, the degradable of ADF, the increase of $\mathrm{NH}_{3}$, TVFA production and microbial populations especially protozoa. improving of IVDMD on gamma irradiation was similar to others study with in sacco methods. Dose of gamma iradiation higher than $50 \mathrm{kGy}$ could increase ruminal DM degradability of feedstuffs [9]. Higher levels of irradiation, up to $600 \mathrm{kGy}$, can be used to improve the rumen degradability of the dry matter of various plant residues and cereal straws [39]. The increase of protozoa population (Table 3) followed by increasing in $\mathrm{CH}_{4}$ cincentration and production (Figure 1 and 2). Bhatta et al. [42] reported that methane production related to the protozoa population. Methane was generated by methanogens bacteria that consumed hydrogen.

\section{CONCLUSSION}

Gamma irradiation pretreatment on SSB is capable of improving in vitro rumen fermentation. The dose of $100 \mathrm{kGy}$ was the best gamma irradiation dose to improve SSB quality. Further study is needed to determine in vivo degradability and economically benefits of this processing. The treatment of reducing $\mathrm{CH}_{4}$ productions is also needed, when gamma irradiated SSB would be used as fiber source in ruminants diets. 


\section{ACKNOWLEDGEMENT}

The author wish to thank Ir. Suharyono, M.Rur.Sci, Shintia Nugrahini Wahyu Hardani A.Md and all members in Animal Production Group. Gratitude is also expressed to Mr Dedi Ansori, Mr Adul and Mr Udin Siman who helped in the field during this project and those who contributed to this paper.

\section{REFERENCES}

1. ANANDAN, S., H. ZOLTAN, A. A. KHAN, D. RAVI and M. BLÜMMEL. Feeding value of sweet sorghum bagasse and leaf residues after juice extraction for bio-ethanol production fed to sheep as complete rations in diverse physical forms. Anim Feed Sci. Tech., 175 (3-4): 131- 136 (2012).

2. SESHAIAH, C. V., Y. R. REDDY, S. J. RAO and M. SRIVANI. Prediction of optimum roughage to concentrate ratio in sweet sorghum (Sorghum bicolor L. Moench) bagasse based total mixed ration for buffaloes using in vitro gas technique. $J$. Adv Vet Anim Res., 1 (4), 224-227 (2014).

3. DESCHAMPS, F. C., L. P. RAMOS and J. D. FONTANA. Pre-treatment of sugarcane bagasse for enhanced ruminal digestion. App Biochem Biotechnol., 57, 177-182 (1996).

4. WRIGHT, C. F., M. A. G. VON KEYSERLINGK, M. L. SWIFT, L. J. FISHER, J. A. SHELFORD and N. E. DINN. Heat and lignosulfonate treated canola meal as a source of ruminal undegradable protein for lactating dairy cows. J. Dairy Sci., 88 (1), 238-243 (2005).

5. DOGARIS, I., S. KARAPATI, D. MAMMA, E. KALOGERIS and D. KEKOS. Hydrothermal processing and enzymatic hydrolysis of sorghum bagasse for fermentable carbohydrates production. Bioresour Technol, 100 (24), 6543-6549 (2009).

6. YAN, Z., J. LI, S. LI, T. CUI, Y. JIANG, G. CONG and M. YU. Impact of lignin content on the sweet sorghum bagasse enzymatic hydrolysis. Energy Procedia, 61, 1957-1960 (2014).

7. BANCHORNDHEVAKUL, S. Effect of urea and urea-gamma treatments on cellulose degradation of Thai rice strawand corn stalk. Radiat Phys Chem., 64 (5-6), 417-422 (2002).

8. SHAWRANG, P. A. NIKKHAH, A. ZARE-SHAHNEH，A. A. SADEGHI, G. RAISALI and M. MORADISHAHREBABAK. Effects of $\gamma$ irradiation on protein degradation of soybean meal. Anim Feed Sci Technol., 134 (1-2), 140-151 (2007).

9. SHAHBAZI, H. R., A. A. SADEGHI, P. SHAWRANG and G. RAISALI. Effects of gamma irradiation on ruminal DM and NDF degradation kinetics of alfalfa hay. Pakistan J. Bio Sci., 11 (8), 1165-1168 (2008).

10. ANWAR, M. M., S. E. ALI and E. H. NASR. Improving the nutritional value of canola seed by gamma irradiation. J. Radiat Res Appl Sci., 8 (3), 1-6 (2015).

11. AL-MASRI, M. R. and M. ZARKAWI. Effects of gamma irradiation on cellwall constituents of some agricultural residues. Radiat Phys Chem., 44 (6), 661-663 (1994).

12. AOAC. Official methods of analysis of AOAC. International. $18^{\text {th }}$ Edition (2010).

13. Goering, H. K. and P. J. Van Soest. Forage Fibre Analysis (apparatus, reagents, procedures, and some application). Agric. handbook 379, ARS., USDA., Washington, DC. USA (1970). 
14. MENKE, K. H., L. RAAB, A. SALEWSKI， H. STEINGASS， D. FRITZ and W. SCHNEIDER. The estimation of the digestibility and metabolizable energy content of ruminant feeding stuffs from the gas production when they are incubated with rumen liquor. $J$. Agric Sci., 93 (1), 217-222 (1979).

15. CONWAY, E.J. Micro-diffusion Analysis and Volumetric Error. Lockwood. London (1950).

16. BLÜMMEL, M., H. STEINGASS and K. BECKER. The relationship between in vitro gas production, in vitro microbial biomass yield and ${ }^{15} \mathrm{~N}$ incorporated and its implication for the prediction of voluntary feed intake of roughages. Br J. Nutr., 77, 911-921 (1997).

17. OGIMOTO, K. and S. IMAI. Atlas of Rumen Microbiology. Japan Scientific Societies Press, Tokyo (1981).

18. ØRSKOV, E.R. and I. MCDONALD. The estimation of protein degradability in the rumen from incubation measurements weighted according to the rate of passage. $J$. Agric. Sci. Camb., 92, 499-503 (1979).

19. STEEL, R.G.D. and J.H. TORRIE. Principles and Procedures of Statistics, $2^{\text {nd }}$ ed., McGraw-Hill., New York (1980).

20. TAGHINEJAD, A., A. NIKKHAH, A. SADEGHI, G. RAISALI and $M$. CHAMANI. Effects of gamma irradiation on chemical composition, antinutritional factors, ruminal degradation and in vitro protein digestibility of full-fat soybean. Asian-Aust J. Anim Sci., 22 (4), 534-541 (2009).

21. SHAWRANG, P., A. A. SADEGHI and J. AHMADPANAH. Ruminal degradation kinetics of wheat straw irradiated by high doses of electron beam. IJAS, 3 (1), 25-29 (2013).

22. SHAWRANG, P., A. A. SADEGHI, M. BEHGAR, H. ZARESHAHI and G. SHAHHOSEINI. Study of chemical composition, antinutritional contents and digestibility of electron beam irradiated sorghum grains. Food Chem., 125 (2), 376-379 (2011).

23. EBRAHIMI-MAHMOUDABAD, S.R. and $M$. TAGHINEJADROUDBANEH. Investigation of electron beam irradiation effects on anti-nutritional factors, chemical composition and digestion kinetics of whole cotton seed, soybean and canola seeds. Radiat Phys Chem., 80 (12), 1441-1447 (2011).

24. GRALAK, M. A., S. MAHMOOD and W. BAREJ. Rumen degradability of dry matter and crude fibre of irradiated and sodium hydroxide treated straws. Arch Anim Nutr., 47 (1), 63-74 (1994).

25. FLACHOWSKY, G., M. B, A. SABINE and K. TIROKE. Cell wall content and rumen dry matter disappearance of irradiated wood by products. Biol Wast., 34 (3), 181189 (1990).

26. DEOCARIS, C. C., A. C. DE VERA, M. M. ELLANA and C. O. ASAAD. In vitro gas production tests on irradiated-chicken feathers to estimate its nutritive value as feed for ruminants. Philipp J. Sci., 132 (2), 83-87 (2003).

27. HENDRIKS, A. T. and G. ZEEMAN. Pretreatments to enhance the digestibility of lignocellulosic biomass. Bioresour Technol, 100 (1), 8-10 (2009).

28. SAMBUSITI, C., F. MONLAU, E. FICARA, H. CARRÈRE and F. MALPEI. A comparison of different pre-treatments to increase methane production from two agricultural 
substrates. Appl Energy, 104, 62-70 (2013).

29. TAKAHASHI, J. Current state and issues of greenhouse gases emitted from animal agriculture in Japan. Proceedings of Greenhouse Gases and Animal Agriculture. Obihiro, Japan, November 7-11. P. 6-14 (2001).

30. SANTOSO, B. and B. T. HARIADI. Evaluation of nutritive value and in vitro methane production of feedstuffs from agricultural and food industry by-products. $J$. Indonesian Trop Anim Agric., 34 (3), 189-195 (2009).

31. SANTOSO, B., B. MWENYA, C. SAR and J. TAKAHASHI. Methane production and energy partition in sheep fed timothy silage or haybased diets. JITV, 12 (1), 27-33 (2007).

32. ESTERMANN, B. L., F. SUTTER, P. O. SCHLEGEL, D. ERDIN, H. R. WETTSTEIN and M. KREUZER. Effect of calf age and dam breed on intake, energy expenditure, and excretion of nitrogen, phosphorus, and methane of beef cows with calves. J. Anim Sci., 80 (4), 11241134 (2002).

33. SHAWRANG, P., A. MAJDABADI and A.A. SADEGHI. Changes in cell wall compositions and degradation kinetics of electron beam-irradiated sugarcane bagasse. Turk J. Vet Anim Sci., 36 (5), 527-532 (2012).

34. MOSS, A. R. and D. I. GIVENS. The effect of supplementing grass silage with soya bean meal on digestibility, in sacco degradability, rumen fermentation and methane production in sheep. Anim Feed Sci Technol., 97 (3-4), 127-143 (2002).

35. SINGH, S., B.P. KUSHWAHA, S.K. NAGA， A.K. MISHRA，A. SINGH and U.Y. ANELE. In vitro ruminal fermentation, protein and carbohydrate fractionation, methane production and prediction of twelve commonly used Indian green forages. Anim Feed Sci Technol., 178 (1-2), 2-11 (2012).

36. WANAPAT, M. and P. ROWLINSON. Nutrition and feeding of swamp buffalo: feed resources and rumen approach. Ital J. Anim Sci., 6 (Suppl. 2), 67-73 (2007).

37. WANAPAT, $M, S$. KANG and K. PHESATCHA. Enhancing buffalo production efficiency through rumen manipulation and nutrition. Buffalo Bull., 32 (1), 258-275 (2013).

38. SHAHBAZI, H. R., A. A. SADEGHI, H. FAZAELI, G. RAISALI, $M$. CHAMANI and P. SHAWRANG. Effects of electron beam irradiation on ruminal NDF and ADF degradation characteristics of barley straw. J. Anim Vet Adv., 7 (4), 464468 (2008).

39. SIDDHURAJU, P., H.P.S. MAKKAR and K. BECKER. The effect of ionizing radiation on antinutritional factors and the nutritional value of plant materials with reference to human and animal food. Food Chem, 78 (2), 187-205 (2002).

40. WAHYONO, T. Fermentability Evaluation of Buffalo Ration Containing Sorghum using In Sacco, In Vitro and RUSITEC (in Bahasa). Thesis. Bogor Agricultural University. Bogor. Indonesia (2015).

41. RUSSELL, J. B. and R. B. HESPELL. Microbial Rumen Fermentation. J. Dairy Sci., 64 (6), 1153-1161 (1981).

42. BHATTA, R., M.M. SARAVANAN, L. BARUAH and C.C. PRASAD. Effect of graded level of tannin-containing tropical tree leaves on in vitro rumen fermentation, total protozoa and methane production. J. Appl Microbiol., 118, 557-564 (2015). 
The Changes of Nutrient Composition and In Vitro

Evaluation on Gamma Irradiated Sweet Sorghum Bagasse

(Teguh Wahyono, dkk.)

ISSN 1907-0322 